\title{
COMMUNICATIVE STRATEGIES OF MASS MEDIA DISCOURSE
}

\section{Filatova O. S., Huzenko S. V.}

\section{INTRODUCTION}

Discourse is the subject of scientific research in the linguistics of the XXI century. Many scientists study this category in semantic, functional, structural aspects. Works of T. van Dijck ${ }^{1}$, D. Schiffrin ${ }^{2}$, V. Karasyk ${ }^{3}$, N. Arutyunova ${ }^{4}$, M. Makarov ${ }^{5}$, T. Radzievska ${ }^{6}$, K. Serazhym ${ }^{7}$ and others are famous in Ukraine and abroad.

From the standpoint of formal, structurally oriented linguistics, discourse is considered as "a language above the level of a sentence or phrase" concept is identified with the concept of text, and the analysis of discourse coincides with the structurally oriented linguistics of a coherent text ${ }^{9}$.

From the standpoint of functionalism, the concepts of discourse and text are differentiated. Discourse is interpreted as "text + situation". This position led to the formation of oppositions: oral discourse and written text; discourse

1 Dijk Teun Adrianus van. (1997) Discourse as structure and process. Sage Publications Ltd. 368 p.

${ }^{2}$ Schiffrin Deborah. (1994) Approaches to Discourse. Oxford [u.a.] : Blackwell. $459 \mathrm{p}$.

Karasyk V. Y. (2002) Yazykovoj kruh: lychnost', kontsepty, dyskurs [Language Circle: Personality, Concepts, Discourse]. Volhohrad : Peremena. 477 p.

${ }^{4}$ Arutiunova N. D. (1988). Typy yazykovykh znachenyj: Otsenka. Sobytye. Fakt [Types of language values: Evaluation. Event. Fact]. Moscow, 1988, 339 p.

5 Makarov M. L. (2003) Osnovy teoryy dyskursa [Fundamentals of Discourse Theory]. Moscow : YTDHK "Hnozys". 280 p.

6 Radziievs'ka T.V. (1998) Tekst yak zasib komunikatsii [Text as a means of communication]. Kyiv. 194 p.

7 Serazhym K. S. (2002) Dyskurs iak sotsiolinhval'ne iavysche: metodolohiia, arkhitektonika, variatyvnist' (na materialakh suchasnoi hazetnoi publitsystyky) : monohrafiia [Discourse as a sociolinguistic phenomenon: methodology, architectonics, variability (on materials of contemporary newspaper journalism)] Kyiv. 392 p.

${ }^{8}$ Schiffrin Deborah. (1994) Approaches to Discourse. Oxford [u.a.] : Blackwell. P. 23-25.

9 Selivanova O. O. (2006) Suchasna linhvistyka: terminolohichna entsyklopediia [Modern linguistics: the terminology encyclopedia]. Poltava : Dovkillia-K. P. 119. 
process and text structure; discourse dialogue and text monologue ${ }^{10}$. In our opinion, this dichotomy is not always justified, because a written text can be considered from the point of dialogicity (coding - decoding); some genres (e. g. report) can be qualified as a written text and as a public speech.

Formal and functional positions to the interpretation of the concept of discourse in two aspects as "speech + text" are combined. The concept of discourse "is widely understood as everything that is said and written, in other words, as speech activity, which is language material"11. This position is prevalent in philosophy, sociology, psychology, and in linguistics. From this point of view, discourse can be monologue and dialogic; oral and written; it is considered as a process and structure.

Terminological transformations have changed the essence of the research methods. In contradistinction to the linguistics of the text, which focuses on the linguistic aspects of the text, discourse analysis involves shifting the emphasis from formal-linguistic characteristics to non-lingual factors of its generation in the communicative environment, under certain circumstances. In view of this, the analysis of discourse is the main methodological basis for the study of the phenomena of mass communication and, in particular, for the study of mass media discourse.

Modern mass media discourse plays an important role in society. The press, radio, television, websites, social networks have become the only channel to replenishing knowledge for most people, creating a picture of the world. The mass media create a significant influence on the formation of public opinion and beliefs of modern citizens.

There is an interaction between the language of the media and the language system as a whole. Researchers determine the main features of mass media discourse: "1) group affiliation (a member of the community shares the views and values of his group); 2) publicity; 3) dissensual orientation (building a dissense situation - contradictions, disagreements with the subsequent discussion); 4) staging and mass orientation (targeted impact on several groups at the same time)",12.

A new type of discourse - the Internet-media discourse was formed at the intersection of mass media and computer discourse. In relation to traditional

${ }^{10}$ Hal'peryn Y. R. (2008) Tekst kak ob'ekt lynhvystycheskoho yssledovanyia [Text as an object of linguistic research]. Moscow : Yzdatel'stvo LKY. (Lynhvystycheskoe nasledye XX veka). P. 18.

11 Makarov M. L. (2003) Osnovy teoryy dyskursa [Fundamentals of Discourse Theory]. Moscow : YTDHK "Hnozys". P. 89-90.

${ }_{12}$ Reshetarova I. V. (2010) Zasoby evfemii v masmedijnomu dyskursi pochatku XXI stolittia [Means of euphemism in the media discourse of the beginning of the XXI century] : avtoref. dys. ... kand. filol. nauk : 10.02.15. Donets'k. P. 11. 
media, Internet media have the following advantages: "1) Multimedia. The Internet allows to combine visual, audio, print and video components of different types of media; 2) Personalization. Each of the Internet users can find information that interests him, information about any area of interest and human existence; 3) Interactivity. The Internet provides dialogue, interaction, feedback between Internet users, in contrast to traditional media; 4) Deficit of intermediaries. Anyone with access to a computer and the Internet can publish information without interference or manipulation" ${ }^{\text {"13. }}$.

The language of modern media is an interesting object of study for modern linguistics. Mass media discourse performs such functions as information and persuasion (argumentativeness). The persuasion is expressed in the formulation of the position (Thesis) and confirmation of its evidence (Arguments). Types and methods of argumentation depend on the communicative-pragmatic goal of the addressee, which is realized through communicative strategies and tactics.

Intentions of the speaker are concentrated in the grammatical structure of discourse, its linguistic expression, so such categories of pragmatics as strategies and tactics are of particular importance for the study of modern Ukrainian mass media discourse because it shapes the linguistic actions of the individual in communication.

In our opinion, in Ukrainian linguistics the problems of selection of communicative strategies of mass media discourse, their language realization are insufficiently studied, which is the purpose of our publication.

\section{Language implementation of information strategy}

A journalistic publication of any genre is a communicative and psychological phenomenon, a complex act of linguistic communication, a product of the realization of the author's (journalist's) plan, his communicative strategies.

The purpose, motivation, circumstances, experience of a journalist are factors that determine his communicative intention - a meaningful or intuitive intention that specifies the internal program of speech.

At first glance, intentionality is a non-linguistic concept, or rather a psychological phenomenon. However, in the aspect "intention - content discourse (text)" this concept refers to the actual linguistic aspects ${ }^{14}$. The author's intention determines the communicative strategy - a complex of speech actions aimed at achieving the communicative goal.

13 Morris M. The Internet as Mass Medium / M. Morris, C. Ogan // Journal of Communication. 1996. Vol. 46. № 1. P. 39-50.

${ }^{14}$ Batsevych F. S. (2004) Osnovy komunikatyvnoi linhvistyky [Fundamentals of communicative linguistics]. Kyiv : Vydavnychyi tsentr "Akademiia”. P. 116. 
The communicative strategy of the speaker is the choice of the communicative intentions and the distribution of parts of information by communicative components. There is a part of communicative behavior or communicative interaction, in which a series of different verbal and nonverbal means is used to achieve a certain communicative goal, the strategic result to which the communicative act is directed. Strategy is a general framework, an outline of behavior.

A single typology of strategies has not yet been created. There are two types of communication strategies: communicative and semantic. The communication strategy is the rules and sequence of communicative actions followed by the addressee. Semantic strategy is a step-by-step content planning of the purpose with the available "language material" (language code) and each step in communication ${ }^{15}$.

Regarding strategies in the discourse of mass media, it is necessary to highlight the semantic strategy of information. This strategy regulates the selection, structuring and presentation in the message (both verbal and nonverbal) of information about the fact, news, which is the basis of information genres.

In addition, the authors of the publications overcome the obstacles associated with the perception of information. Thus, the communicative strategy in the media discourse is aimed at organizing the impact of the message, it is a strategy to attract attention.

Strategies of both types are combined to create an effective journalistic publication. The communicative strategy depends on the genre of the journalistic text, the dominance of rational-logical or emotional-rhetorical types of structures in it and the delineation of certain compositional and stylistic parameters.

In information genres, the leading semantic communicative strategy is implemented in the text structure. Thus, the main news - the information basis of the publication - is usually presented in the foreground (in the headline) on the principle of an inverted pyramid, according to which the information in the text is distributed in descending order of importance, for example:

“Організатори Свробачення повідомили, де пройде конкурс у 2021 році

Члени Свропейської спілки мовників (ЕВU) та представники Нідерландів домовилися про проведення пісенного конкурсу Свробачення-2021 у Роттердамі на Ahoy Arena.

${ }^{15}$ Ibid. P. 119. 
Саме ие місто мало прийняти конкурс у 2020 роиі, який скасували через пандемію коронавірусу.

"Ми надзвичайно радi, що тепер можемо рухатися вперед. Надзвичайно важливо, щоб пісенний конкурс Євробачення повернувся в наступному році, $і$ ми раді прийняти необхідне зобов'язання наших колег у Нідерландах повернути це видовище глядачам у всьому світі", сказав виконавчий керівник Свробачення Мартін Естердал.

На сьогодні 18 артистів, запланованих на 2020 рік, підтвердили, щяо знову представлятимуть свою країну у 2021 рочі. Детальнішу інформацію організатори обічяють розповісти найближчими тижнями та місяиями” (День).

At the beginning of the text, in particular in the title, the words most interesting from the position of the addressee are made, it becomes the semantic accent of the publication and promotes the implementation of the communicative strategy of attracting attention, communicative strategies are intertwined.

The information message should answer the classic questions: who, what, where, when, how and why. Thus, the main semantic accents can be the subject, object, event, place, time, characteristic (quality, quantity, etc.), cause or method. An analysis of journalistic publications indicates that the main communicative focus of the message is information about the subject or object, which is submitted to the beginning of the article. It may be subjects: “Влада Гаїті назвала нову иифру жертв землетрусу” (Ліга новин); "Прокуратура вимагає розформувати "Оперативний загін” (УНІАН); "Украӥна може зірвати участь у міжнародному проекті "Циклон-4" (УНIAH); “Кличко: більшість інфікованих COVID-19 не уявляли, через що їм доведеться пройти для одужання” (УНІАН); objects direct: "Бібліотеку в Москві знову обшукали" (УП); "Усіх кандидатів на голову НСЗУ відхилили, тепер очільника можуть обрати без конкурсу" (УП); "Презентацію іPhопе 12 перенесли через коронавірус - ЗМI" (УП); objects indirect: “До наркотиків додавали бензин, фосфор і “Містер Мускул” (УП); “Зеленському пожалілись на мовні квоти для ТБ - він сказав, щзо треба “навести порядок” (УП).

If the information about the event is the main one, in the author's opinion, then the predicate is used at the beginning, е. g.: "Розпочались протести у Португалії” (Новий канал); “Порушено справу за фактом “легкого” побиття депутатів у Раді" (Ліга новин); “3'явилися свіжі дані щодо заражених коронавірусом у світі на ранок 15 травня” (УНІАН); "Презентовано план зі створення півмільйона робочих місиь” (Урядовий портал); “Продовжуємо повертати наших громадян до України з різних куточків світу - Мінінфраструктури” (Урядовий портал); “Відкрито нову планету, щяо схожа на Землю” (Euronews). 
As the factual material shows, the structure of an impersonal sentence is most often used for information about an event, the attention is focused on the effectiveness of the action.

Information about the place of the event can become another semantic emphasis, which is conveyed by the adverbial modifier of place at the beginning of the publication: "На “пташиному ринку" в Києві заборонили продавати собак $і$ кішок” (ForUm); "У Бразилії потоки бруду і каменів накрили иілі квартали” (Ліга новин); “У Тунісі помер журналіст, поранений під час протестів" (УНІАН); "У Китаї побудували найдовшу в світі швидкісну залізничну магістраль" (Дзеркало тижня); “У Мінінфраструктури запланували завершити реконструкцію злітної смуги в Одеському аеропорту в червні” (Урядовий портал); “У “Борисполі” оформили евакуачійні рейси з $О A E$ та Вірменї” (Урядовий портал); “У канали Венеції повернулись гондоли" (УП).

Rarely the main focus is the adverbial modifier of time, which is explained by the purpose of information publications - to report new, relevant information, to confirm that the fact is new and does not require updating. In this case, the adverbial modifier of time becomes a means of expressing a communicative strategy of attracting attention to the message: “Сьогодні в Ужгороді буде морозно $і$ ясно” (Zaholovok.com.ua); “6 грудня Рада розгляне проект бюджету на 2013 рік” (УНІАН); "Учора літаками з Туреччини, Сгипту та ОАЕ до "Борисполя" прибуло понад 400 пасажсиів” (Урядовий портал); “За рік ФОПівайтішників в Украӥні побільшало на 22\% (інфографіка)” (УНІАН). Most often, attention is focused on the time of events that have not yet taken place, but are only announced.

The aspect of characterization (quantitative or qualitative) often becomes the main thing in information report, it carries important new (sometimes sensational) information. The subject is the combination of a cardinal numeral with a noun, it helps to reproduce the quantitative characteristics of phenomena, especially in the absence of reader time, e. g.: “Два начальники обласних УВС усунені від роботи через ДТП” (Ліга. Новини); “40 відсотків урожаю кукурудзи у світі отримують США” (Газета поукраїнськи).

There is also a combination of collective numerals with nouns: "П'ятеро украӥнців зламало илагбаум на украӥно-російському кордоні" (КорреспонденТ.net). Attention to the qualitative characteristics of the news can be attracted by an attribute in the starting position, e. g.: “Скандальне затримання в Івано-Франківську" (Галицький кореспондент); “Найдорожчий житловий будинок Великої Британї 
оиінили в $\$ 487$ мільйонів” (Газета по-українськи). In such cases, communicative strategies of informing and attracting attention are reconnected.

Notification of the cause of the event is not the main in the information messages, but attention to this aspect is sometimes realized through the adverbial modifiers of cause: "Внаслідок пожежі постраждала 38-річна безпритульна жінка" (Korabelov.info); "Через землетрус в 7,3 бали на Японію насувається иунамі" (Ukr.Net); “За хабар затримані голова райдержадміністраиії і два депутати” (УНІАН).

The criterion of reliability of information is important for modern journalism, so the message about the source of information can also be the content focus of the publication. Introductory phrases are actively used in a strong initial position, indicating the source of information, e. g.: " $3 a$ даними соціологічних досліджень, 43\% украйнців вважають себе успішними та щасливими” (Перший Національний); “За останніми даними, число жертв вибуху в Пакистані досягло 35 осіб” (РБКУкраїна). The authors use them to convince information, increase the degree of its reliability, this is very important for the media. An individual can be a source of information, е. g.: “На думку Володимира Литвина, поглиблення відносин України з $е$ на користь $i$ самому співтовариству" (Перший Національний). Authors can report the source of information using constructions of complex sentences with an incomplete first part: "CNN: У США повідомляють про успішне випробування ліків від корона вірусу” (Українська правда); “УМВС: екологи сприяли незаконному виділенню землі під супермаркет” (КорреспонденТ.net). The first part of these sentences is concise, it omits the predicate, which is clear in context, e. g.: "УМВС: екологи сприяли незаконному виділенню землі під супермаркет” $\leftarrow$ УМВС повідомляє, щзо екологи сприяли незаконному виділенню землі під супермаркет та ін.

Further information about other characteristics of the event (place, time, qualities, reasons, additional details) is provided in the main text. The sequence of answers to the key questions of information texts depends on the author. He shows his creativity, his attitude to the event, own position.

Reporting the facts, the author implements a semantic strategy of information, for example, we have selected factual information (names, dates, quotes, etc.), e. g.:

"У Львові відбудеться засідання 3 придністровського врегулювання"

У лютому у Львові пройде чергове офіційне засідання "Постійної наради з політичних питань у рамках переговорного процесу 3 придністровського врегулювання" (формат “5+2”). 
Про ие УНІАН повідомили в Департаменті інформації та преси МЗС РФ за підсумками сьогоднішньої зустрічі статс-секретаря заступника глави МЗС РФ Григорія Карасіна $i$ політичного представника в процесі придністровського врегулювання, заступника глави уряду, міністра закордонних справ Придністров'я Ніни Штанські.

“У ході розмови, що відбулася, обговорювалася сучасна ситуація в придністровському врегулюванні, а також питання підготовки до чергового офіційного засідання "Постійної наради з політичних питань у рамках переговорного процесу з придністровського врегулювання", - йдеться в повідомленні.

Формат “5+2" передбачає участь $y$ переговорах двох конфліктуючих сторін - Молдови $\boldsymbol{i}$ Придністров'я; трьох посередників - Росії, Украӥни і ОБСЕ; а також двох спостерігачів CШ $\boldsymbol{A}$ i $\boldsymbol{C C}$ " (УНIAH).

\section{Linguistic implementation of the strategy of attracting attention}

The communicative strategy of attracting attention is mostly implemented through conciseness, brevity, specificity of the transfer of factual information. There are examples of expressing the assessment of events, the author's expression through exclamatory sentences, linking words, etc.: "За попередньою інформацією, рівень шуму, який виробляє автомобіль під час руху, до 2020 року повинен скоротитися рівно вдвічі! ... Мало того, закон може вдарити і по мотоциклам, які, на думку багатьох експертів, $\epsilon$ в деяких містах основним джерелом шуму на вулииях" (Newsone).

Using an emotionalization strategy is one of the ways of drawing attention to the publication. "Emotions can be represented in various ways: from quotations and references to the authoritative opinion, statistical data, direct expression of the author's personal opinion to emotionally marked words including common nouns, personal pronouns, viewpoint adverbs, propositional predicates, adjectives with emotive meaning and numerals"16.

Researchers emphasize that "in order to manipulate the reader, the author not only does seek the identification with the readers' opinion, but also tends to improve his own reputation by creating an image of an emotional person who expresses his feelings openly, which, in turn, undoubtedly inspires

${ }^{16}$ Teneva E. V. (2018) Emotionalisation Strategy as a Means of Manipulation in the British Mass Media Discourse Russian Linguistic Bulletin. № 3 (15). https://doi.org/ 10.18454/RULB.2018.15.3.4 
confidence in the audience and raises the authority of both the author himself and the information he provides" ${ }^{\prime 17}$.

The function of influence is one of the most important functions of media discourse. It can be realized only by attracting attention to a person, by creating a situation of dialogue.

Dialogicity as a discursive category is based on the understanding that the participants in the discursive process are the subjects of speech: the author and the addressees. People tend to exchange opinions and information. Textual dialogicity has two sides - addressability and reversibility (act in response). On the one side, the author indicates to the reader the direction of reflection, the deployment of textual content. The addressee of the mass media discourse perceives the text on the informative and semantic levels, the feedback is formed in his mind, there is a kind of dialogue. Dialogicity in the mass media discourse is expressed in the genre of interviews, but in monologue texts this category is also revealed.

Dialogicity has a dual direction and functioning: on the one side it can be an internal dialogue (egocentric), on the other side it can be an open dialogue that involves interaction and communication with another person.

Researchers have determined the means of expressing dialogicity on the example of scientific texts: "conversation" with another person, ideological (theoretical) opponents or like-minded people; comparison of two or more points of view, which are evaluated by the author; "conversation" with the reader, involving him in common considerations, the desire to attract his attention to the message's content; "conversation" with his second, objectified "I" (in the text it is presented as a dialogue-introspection, selfcontrol or dialogue for verify the evidence)" $" 18$.

The analysis of the factual material (on the example of the materials of Ukrainian periodicals) convincingly proves that the mass media discourse is characterized by signs of dialogicity.

An example of explicit dialogue is interviews as a genre and as a method of obtaining factual material. The "conversation" is implemented in the format of "question-answer" or in the form of direct or indirect speech: "Чи могла українська журналістика з самого початку незалежності піти іншим шляхом? ... - Усі могли піти іншим шляхом - $i$ журналісти, i газовики, i банкіри...” (Дзеркало тижня). In such examples, interrogative

${ }^{17}$ Teneva E. V. (2018) Emotionalisation Strategy as a Means of Manipulation in the British Mass Media Discourse Russian Linguistic Bulletin. № 3 (15). https://doi.org/ 10.18454/RULB.2018.15.3.4

18 Stylystycheskyj entsyklopedycheskyj slovar' russkoho iazyka [Stylistic Encyclopedic Dictionary of the Russian Language] (2003). Moscow: Flynta. P. 47-48. 
constructions are the marker of dialogicity, it involves feedback. The reader observes the development of thought, participates in the dialogue mentally.

Evaluate contributes to the creation of a common cognitive field between the author and the addressee, forms an implicit dialogue. In contrast to scientific and other texts in journalism we will hardly find the author's assessment expressed by constructions "як слушно зауважив...". The authors adhere to one of the rules of journalistic ethics, associated with the separation of factual information from the evaluative.

Means of speech influence are more often used in mass media discourse. In order to attract to the "single" circle of interlocutors the authors of publications use pronouns: "we, our etc.", е.g.: "Ми вже ніколи не зможемо перевиховати тих дорослих харків'ян" (Український тиждень); “А зараз ми побачимо, як звучало те публічне "зізнання в любові" до Польщі, виголошене перед пам'ятником на честь Варшавського повстання" (Український тиждень).

For the purpose of suggestion, the authors utilize verbs of the imperative mood, e. g.: "Тепер спробуємо поглянути на те, щцо відбулося 3 економікою окремих регіонів Украӥни за останні три роки, тобто порівняно з довоєнними часами" (Український тиждень). In this way, the author engages the addressee in a joint action, waiting for the opposite reaction - an internal dialogue.

Direct interrogative constructions involve joint reflections, considerations and actively attract attention. The authors use interrogative sentence constructions: "Чи задумувалися ви, чим нині можна здивувати свою дитину?” (Дзеркало тижня); interrogative-rhetorical constructions: "Що стоїть перешкодою на иьому шляху? Яких змін прагне вітчизняна деревообробка?” (Дзеркало тижня); “Як з'являються міфи?” (ДТ]; "Навімо вам читати про науку?" (Український тиждень); "Чи стануть техногіганти ще могутнішими після кризи?" (Український тиждень); “Приватна сонячна електростанщія: наскільки ие вигідно?” (Український тиждень); “Покоління Z: політика чи романтика?" (Український тиждень).

There are examples in which we observe both involvement in the "single" circle of interlocutors, and a rhetorical question: "Чи маємо ми впевненість у наших иінностях, щзоб боротися за них аж до кіния? Чи маємо достатньо поваги до наших громадян, щоб охороняти наші кордони? Чи маємо відвагу, щчоб зберегти нашу ичивілізацію перед лицем тих, хто хотів би підпорядкувати іï собi ц̌ знищити?” (Український тиждень); "Якщо закрити державні кордони можна у наказовому порядку, то як змусити кожного окремого громадянина вчасно мити руки та зайвий раз не торкатись обличчя?" (Украӥнський тиждень). 
Internal dialogue is one of the means of creating dialogicity in mass media discourse. In essence the question is rhetorical. Then the author answers it himself, sometimes also with questions, expressing his own opinion and convincing the reader, for example: "Ви спитаєте, щь таке щастя? А чи можна навчити дитину бути щңасливим колись в майбутньому, позбавляючи його стану щастя в сьогоденні,... якою вона повинна бути в майбутньому, $i$ як вона повинна вести себе сьогодні?” (Українська правда); “Хіба зберегти таку колекиію не $\epsilon$ державним інтересом? Не будемо заглиблюватися в історію. А втім, чому б $і$ ні? ” (Дзеркало тижня); “Закінчення війни чи перемога? А хіба не однаково? Конфлікт на Донбасі чи російсько-украӥнська війна? Облиште, ми ж не політики! Ополченці чи сепаратисти, а може, російсько-терористичні угруповання? Господи, навіщо нам сперечатися щцодо щьього? Ми ж усі про те саме! Чи ні?” (Украӥнський тиждень).

Rhetorical appeals are an example of dialogicity in mass media discourse In this way the author activates the addressee's attention: "Найцікавіше, друзі, ще попереду!” (Дзеркало тижня); “Украӥнці - читайте!” (День, назва рубрики).

In addition, interrogative constructions, interrogative-rhetorical, rhetorical appeals, and constructions "question-answer" are the means of implementing a communicative strategy to create a problem situation, a situation of contradiction, which will provoke further discussion: internal or public (in comments, in newspapers, on screens, in social networks, etc.).

\section{Means of implementing the strategy of argumentation}

The communicative-pragmatic goals of argumentative discourse are to change the beliefs of the addressee, to prove the truth of the proposed thesis, to control the consciousness of the addressee with a view to possibly change his model of the world. The main strategic problem of the argumentative discourse is the implementation of a persuasive effect, realized through various tactics. It unites all goals ${ }^{19}$.

The logical structure of argumentation consists of three components. These are a thesis or a judgment that needs to be proved and arguments or true judgments that are used in the process of proving a thesis. Finally, a

19 Bohacheva M. V. (2010) Arhumentatyvnaia kommunykatyvnaia stratehyia y taktycheskye pryemy realyzatsyy $\mathrm{v}$ russkom yazyke [An argumentative communicative strategy and tactical methods for its implementation in Russian]. Visnyk Dnipropetrovskoho universytetu. Seriia "Movoznavstvo" [Bulletin of Dnipropetrovsk University. Linguistics Series]. Vyp. 16. http://archive.nbuv.gov.ua/portal/natural/vdpu/ Movozn/2010_16/9.pdf. 
form of proof or a demonstration is a way of logical connection between the thesis and arguments, or the process of developing arguments. Argumentation can be carried out in two main ways: by direct reference to reality, which is often done by a journalist (factual argumentation), and by using known provisions, judgments, when the author also refers to reality, not directly, but indirectly, through inferences, conclusions, laws, concepts, theories, etc. ${ }^{20}$

At the textual level, the thesis can be formulated at the beginning of a journalistic article, at the beginning of paragraphs, in a journalist's question in an interview etc. Arguments are the most interesting for linguistic analysis.

The purpose of any argument is to approximate the ideas of communicators. Depending on whether the argument is focused on the rational or emotional sphere, semantic strategies of rational and emotional impact are distinguished ${ }^{21}$

The analysis of factual material showed that in the texts of analytical genres of modern media, communicative strategies of rational influence are realized through tactics of reference to authority. Insert phrases are language markers of this tactic, е. g.: "На думку президента Польщі, вже зараз треба думати про роботу після саміту у Вільнюсі" (Український тиждень). Direct speech is also language markers, e. g.: "Виникає запитання, в яких масштабах їх використовуватимуть. Якщо вони замінять живі гроші, то на якомусь етапі з економіки вони вимиватимуться, а без них вона просто не праиює, - пояснює Ігор Бураковський, голова правління Інституту економічних досліджень та політичних консультацій” (Український тиждень). Using information from authoritative sources attracts the audience's attention to the content and to the author of the quote. Not only contemporaries, but also classics can be quoted, it helps to convince the addressee, е. g.: "І... ще кілька цитат із видатного політика й мудрого чоловіка Франкліна Делано Рузвельта: “Справжня особиста свобода неможлива без економічної безпеки й незалежності" - в яблучко! I зовсім останнє: “Едине, чого ми маємо боятися, то ие самого страху” (Український тиждень).

The tactics of giving examples - factual information, statistical data, results of experiments - play an important role in journalism. The use of factual argumentation is mandatory for journalism, because the journalist's

${ }^{20}$ Zdoroveha V. Y. (2004) Teoriia i metodyka zhurnalistskoi tvorchosti [Theory and methods of journalistic creativity]. Lviv : PAIS. P. 134.

${ }^{21}$ Yvyn A. A. (1997) Osnovy teoryy arhumentatsyy. [Fundamentals of the theory of argumentation] Moscow : Humanyt. yzd. tsentr VLADOS. P. 119-313. 
strategic task is to "recreate the picture of reality", and report on current events. The basis of publications of analytical genres is interpretation, analysis of events, comments on them. With the help of facts a certain thesis is proved, for example, a thesis is a statement in the publication: "Teмn приросту капіталовкладень в агробізнес лишається одним із найбільших в украӥнській економіиі, а сама галузь дістала тепличні умови для розвитку". Evidence facts are introduced in sentences interconnected by introductory words, e. g.: "По-перше, кредитна політика банків стала лояльнішою до аграріїв. По-друге, значні податкові преферениії для агробізнесу. За весь минулий рік великі та середні сільгосппідприємства отримали 27 млрд грн чистого прибутку, але внесли при иьвому менше ніж 1\% сплаченого всіма підприємствами в Україні податку на прибуток. По-третє, після чергового переділу зернового ринку трейдери, власники яких є наближеними до влади, дістали широкі можливості для вивезення збіжжя з країни: у 2012/13 маркетинговому роиі було поставлено на експорт майже 23 млн $m$ зернових" (Український тиждень).

In content, rational arguments can be of a factual type: quotes from documents, statistics, actually factual material, for example, statistical information: "Згідно з офіиійною статистикою МОЗ України, 2012 року на обліку перебували 79 тис. наркозалежних осіб, з яких 70 тис. вживали наркотичні речовини або психотропні засоби ін'єкційним способом (тобто йдеться про хронічну залежність)", (Український тиждень).

Legal reasoning is common enough. This may be a reference to the Constitution of Ukraine, legislative acts: "У иілому високої оиінки заслуговує закон "Про наукову і науково-технічну діяльність" (1999, з подальшими змінами), що вимагає фінансування науки 3 держбюджету в обсязі, не меншому за 1,7\% ВВП, декларує демократичні принципи організації науки, передбачає встановлення високих наукових пенсій, які забезпечували б престиж праці науковия" (Український тиждень).

Texts of analytical genres are characterized by reliance on moral and ethical rules, since journalism operates in the field of social relations based on moral standards. The description of these norms can confirm the thesis, е. g.: “...специфіка явища “мажорства" криється у характері демонстраиії свойх широких можливостей іншим. Що молодша особа, то примітивніший цей показ..." (Український тиждень).

As already noted, the strategic task of analytical texts is to convince the addressee, which provides a logical and psychological impact on the consciousness. In this process, new information, new knowledge is 
associated with the views, attitudes, stereotypes, and ideas that already exist in the mind. Secondly, this knowledge is recognized as a personal discovery of the reader. The presentation of journalistic information, bringing the audience to certain conclusions should be so subtle and inconspicuous that the person himself draws conclusions. Then they can become her beliefs. Third, only an emotional idea can become a belief. Given this, the role of the emotional type of argumentation is growing.

So, the author can use emotionally colored vocabulary, colloquial clichés that bring closer the position of communicants, e.g.: "Розквіm журналістських розслідувань в країні ніяк не заважає ї̈ дерибану. Навпаки, дерибан набув небачених масштабів $i$ досконалості", (Український тиждень); “Ситуативна більшість у парламенті, якої нібито ось-ось мали досягти, розвіється, як фата моргана" (Український тиждень).

Rhetorical questions perform the function of emotional affirmation, e. g.: “Що ж святкує російський президент? Відновлення серійного виробництва Ан-124? Будівництво мосту через Керченську протоку? Допуск украӥнських иукерок $i$ сиру до московських супермаркетів? Невже спільне відзначення 200-річчя Шевченка?" (Український тиждень).

In addition to arguments to confirm the thesis, the author seeks to change the views of the addressee in analytical publications. To implement these intentions, he uses assurance tactics, e. g.: "У компанії запевняють, що “заява Міністерства юстииї про те, щзо Єдині $і$ Державні реєстри працюють точно так само $і$ в тому ж вигляді, що $і$ до 1 жовтня 2013 року, є безпідставною" (Український тиждень); or requirements tactics: "Стале зростання ставок за вкладами неможливе: щоби банки вчасно та в повному обсязі сплачували відсотки й повертали гроші, вони мають працювати, тобто ӥх треба спрямувати на кредитування" (Український тиждень).

Assumption tactics are important enough for modeling the picture of the addressee's world, e. g.: “Власне, якби Сальвадор Альєнде був обраний на президентку посаду в 1970 році більш демократично, а не 36 відсотками голосів вибориів, він би, скоріме за все, не демонстрував свою неповагу до основних демократичних приниипів" (Український тиждень). Forecasting tactics are also considerable, e. g.: "Позбувшись парламентської опозииії, маючи змогу вводити надзвичайний стан за надуманими мотивами, режим Януковича, вочевидь, сподівається різко змічнити свої позиції не лише в країні, а й у переговорах із зовнішніми партнерами. При иьвому, безперечно, про євроінтеграцію не йтиметься, але вона, як уже неодноразово 
писав Тиждень, і не є метою режиму Януковича. Натомість такий сиенарій створюватиме сприятливі умови для подальшої розбудови в Україні “сімейної” моделі, частково з використанням білоруських лекал” (Український тиждень).

These tactics allow the thoughtful reader to compare the text with objective reality and draw his conclusions (or conclusions that the author needs), e. g.: "Таким чином, порушення прав людини, котрі були скоєні військовою диктатурою пізніше, повинні бути відокремлені від безпосередньо військового перевороту, який був широко підтриманий переважною більшістю чилійського суспільства" (Український тиждень).

\section{CONCLUSIONS}

The study of some aspects of the implementation of the author's communication strategies in the language of information genres convinces us in the creation of semantic accents of publications by bringing to a strong starting position the most important information about the subject, object, time, place, event characteristics and so on. In the main text, the leading strategy of a journalist is an information strategy, which is implemented through maximum attention to factual information. The result of the implementation of the strategy of attracting attention is the conciseness and expressiveness of the structures.

The study of dialogic manifestations in mass media discourse emphasizes that drawing attention to the linguistic identity of both the author and the addressee is very important for this type of discourse. The use of this category is directly related to the expectation of feedback, community's reaction to the messages.

The main semantic strategy of argumentative discourse is the implementation of convincing influence, which is realized through informative tactics: appealing to authorities and giving examples. Moreover arguments can be rational and emotional types. Influence on the beliefs of the addressee occurs through the use of tactics of assurance, requirements, etc. Tactics of assumption, predictions, conclusions are used to model the world of the addressee.

Further detailed study of the linguistic implementation of these strategies is a prospect for scientific research.

\section{SUMMARY}

Since mass media discourse plays an important role in modern society, it is important to study how the influence of people's consciousness occurs. such categories of pragmatics as strategies and tactics acquire special 
significance, because they form the speech actions of the person in the process of communication.

In the mass media discourse, the main communication strategies are aimed at informing the addressee (transmission of content), the impact of the information message (including attracting the attention and persuasion of the addressee). Tactics associated with this are analyzed in our publication.

In the section, the authors investigate some aspects of the implementation of informative and argumentative communication strategies in the language of publications of informational, analytical genres. Attention is paid to the language means of creating semantic accents in journalistic materials. An analysis of journalistic publications indicates that the main communicative focus of the message is information, which is submitted to the beginning of the article.

The author of the article argue that by creating a dialogue situation, the textual function of influencing the publication's recipient is realized, between the author and the addressee of the message a single cognitive field is formed. Communicative tactics of creating a problem situation, a situation of contradiction provoke further discussion, internal or public (in comments, in newspaper columns, on screens, in social networks, etc.).

Argumentative tactics influencing the change of the picture of the world of the addressee are identified. It is proved that arguments can be of rational and emotional types. Examples of implementing strategies for informing and attracting attention are given.

\section{REFERENCES}

1. Arutiunova N. D. (1988). Typy yazykovykh znachenyj: Otsenka. Sobytye. Fakt [Types of language values: Evaluation. Event. Fact]. Moscow, 1988, 339 p. [in Russian].

2. Batsevych F. S. (2004) Osnovy komunikatyvnoi linhvistyky [Fundamentals of communicative linguistics]. Kyiv: Vydavnychyi tsentr "Akademiia". 342 p. [in Ukrainian].

3. Bohacheva M. V. (2010) Arhumentatyvnaia kommunykatyvnaia stratehyia $\mathrm{y}$ taktycheskye pryemy realyzatsyy $\mathrm{v}$ russkom yazyke [An argumentative communicative strategy and tactical methods for its implementation in Russian]. Visnyk Dnipropetrovskoho universytetu. Seriia "Movoznavstvo" [Bulletin of Dnipropetrovsk University. Linguistics Series]. Vyp. 16. http://archive.nbuv.gov.ua/portal/natural/vdpu/Movozn/ 2010_16/9.pdf. [in Russian].

4. Dijk Teun Adrianus van. (1997) Discourse as structure and process. Sage Publications Ltd. 368 p. [in English]. 
5. Hal'peryn Y. R. (2008) Tekst kak ob'ekt lynhvystycheskoho yssledovanyia [Text as an object of linguistic research]. Moscow: Yzdatel'stvo LKY. 144 p. (Lynhvystycheskoe nasledye XX veka). [in Russian].

6. Karasyk V.Y. (2002) Yazykovoj kruh: lychnost', kontsepty, dyskurs [Language Circle: Personality, Concepts, Discourse]. Volhohrad : Peremena. 477 p. [in Russian].

7. Makarov M. L. (2003) Osnovy teoryy dyskursa [Fundamentals of Discourse Theory]. Moscow : YTDHK "Hnozys". 280 p. [in Russian].

8. Morris M., Ogan C. (1996) The Internet as Mass Medium. Journal of Communication. Vol. 46. № 1. P. 39-50. [in English].

9. Mykhailyn I. L. (2011) Osnovy zhurnalistyky [Fundamentals of journalism]: Kyiv : Tsentr uchbovoi literatury. 496 p. [in Ukrainian].

10. Radziievs'ka T. V. (1998) Tekst yak zasib komunikatsii [Text as a means of communication]. Kyiv. 194 p. [in Ukrainian].

11. Reshetarova I. V. (2010) Zasoby evfemii v masmedijnomu dyskursi pochatku XXI stolittia [Means of euphemism in the media discourse of the beginning of the XXI century] : avtoref. dys. ... kand. filol. nauk : 10.02.15. Donets'k. 20 p. [in Ukrainian].

12. Schiffrin Deborah. (1994) Approaches to Discourse. Oxford [u.a.] : Blackwell. 459 p. [in English].

13. Selivanova O. O. (2006) Suchasna linhvistyka: terminolohichna entsyklopediia [Modern linguistics: the terminology encyclopedia]. Poltava : Dovkillia-K. 716 p. [in Ukrainian].

14. Serazhym K. S. (2000) Struktura publitsystychnoho tekstu: zahal'ni pidkhody do tekstolohichnoho analizu [Structure of journalistic text: general approaches to textual analysis]. Naukovi zapysky instytutu zhurnalistyky [Scientific notes of the Institute of Journalism]. Kyiv : KNU. T. 1 (zhovten'hruden'). Pp. 103-114. [in Ukrainian].

15. Serazhym K. S. (2002) Dyskurs iak sotsiolinhval'ne iavysche: metodolohiia, arkhitektonika, variatyvnist' (na materialakh suchasnoi hazetnoi publitsystyky): monohrafiia [Discourse as a sociolinguistic phenomenon: methodology, architectonics, variability (on materials of contemporary newspaper journalism)] Kyiv. 392 p. [in Ukrainian].

16. Stylystycheskyj entsyklopedycheskyj slovar' russkoho iazyka [Stylistic Encyclopedic Dictionary of the Russian Language] (2003). Moscow: Flynta. 696 p. [in Russian].

17. Teneva E.V. (2018) Emotionalisation strategy as a means of manipulation in the British mass media discourse. Russian Linguistic Bulletin. № 3 (15). https://doi.org/10.18454/RULB.2018.15.3.4 
18. Yvyn A. A. (1997) Osnovy teoryy arhumentatsyy. [Fundamentals of the theory of argumentation] Moscow: Humanyt. yzd. tsentr VLADOS. 352 p. [in Russian].

19. Zdoroveha V. Y. (2004) Teoriia i metodyka zhurnalistskoi tvorchosti [Theory and methods of journalistic creativity]. Lviv: PAIS. $268 \mathrm{p}$. [in Ukrainian].

\section{Information about the authors:}

Filatova O. S.,

Doctor of Philology, Professor,

Department of Social Studies and Humanities, Admiral Makarov National University of Shipbuilding 9, Heroes of Ukraine Avenue, Mykolaiv, 54025, Ukraine ORCID ID: orcid.org/0000-0002-4464-6933

Huzenko S. V., $\mathrm{PhD}$ in Philology, Associate Professor at the Department of Modern Languages, Admiral Makarov National University of Shipbuilding 9, Heroes of Ukraine Avenue, Mykolaiv, 54025, Ukraine ORCID ID: orcid.org/0000-0001-8177-7417 